\title{
Doppler Ultrasonography for Evaluating Vascular Responses to Ergopeptine Alkaloids in Livestock
}

\author{
G.E. Aiken and J.R. Strickland \\ USDA-Agricultural Research Service, \\ Forage-Animal Production Research Unit, \\ Lexington, $K Y$, \\ USA
}

\section{Introduction}

Ergot alkaloids are produced by non-spore producing fungal endophytes that infect certain species of grasses, most notably tall fescue [Lolium arundinaceum (Schreb.) Darbysh.] and perennial ryegrass (Lolium perenne L.), and the spore producing Claviceps spp. that infect seed heads of certain grasses and particularly the cereal grains [rye (Secale cereal L.), barley (Hordeum vulgare L.), wheat (Triticum aestivum L.), , and oats (Avena sativa L.)] (Strickland et al., 2011). Ergot alkaloids induce a toxicosis in grazing livestock, with symptoms in cattle that include rough hair coats during the warm season, severe heat stress in warm and humid temperatures, reduced dry matter intake, agalactia, and poor reproductive and weight gain performance (Porter \& Thompson, 1992; Paterson et al., 1995). Sheep grazing endophyte-infected fescue also can have elevated core body temperatures in warm and humid environments (Zanzalari et al., 1989; Hanna et al., 1990), and reduced dry matter intakes (Chestnut et al., 1992; Aldrich et al., 1993). The most pronounced effect on horses is observed with broodmares, which can exhibit prolonged gestation and agalactia (Cross et al., 1995). Symptomatology of the malady are reflective of alterations in hormone profiles (Porter \& Thomson, 1992; Browning et al., 1997, 1998) and reductions in blood flow to peripheral tissues caused by interactions of ergopeptine ergot alkaloids with biogenic amine receptors in the vasculature (Oliver et al., 1998) to induce persistent vasoconstriction and restrict regulation of core body temperature by the sympathetic nervous system (Oliver, 1997). Consequently, lack of thermoregulation by livestock exposed to ergopeptines are extremely vulnerable to heat and cold stresses (Hemken et al., 1981; Al-Haidary et al., 2001).

Ergot alkaloids contain a common tetracycline ergoline ring structure and there are 3 different classes: 1) clavine alkaloids, 2) lysergic acid and its derivatives, and 3) ergopeptines (Lyons et al., 1986; Bush and Fannin, 2009; Strickland et al. 2011). Ergopeptines exert the greatest influence on the vasculature, with ergovaline being the ergopeptine of highest concentration in tall fescue (Lyons et al., 1986) and with a demonstrated high potency as a vasoconstrictor (Klotz et al., 2006). 
Reduced blood flows in cattle and sheep consuming endophyte-infected tall fescue was first reported by Rhodes et al. (1991) who used radioisotope labeled microspheres to estimate flow rates between those consuming endophyte-infected and endphyte-free tall fescue. Vascular dysfunction is also evidenced by in vitro findings of ergovaline induced constriction of bovine lateral saphenous veins (Klotz et al., 2006, 2007), uterine and umbilical arteries (Dyer, 1993), and rat tail and guinea pig iliac arteries (Schoning, et al., 2001). Caviceps spp. do not produce ergovaline, but can produce high quantities of ergotamine. Blaney et al. (2009) indentified ergotamine as the dominant ergopeptine produced by Claviceps purpurea sclerotia, which is the ergot that infects Australian rye. Blaney et al. (2011) reported severe hyperthermia in steers fed feedyard rations containing sorghum infected with Claviceps Africana, as compared to steers consuming non-infected sorghum.

Color Doppler ultrasonography has been used with humans as a noninvasive technique for real time diagnoses of aberrant blood flow (Someda et al, 1995; Whelan and Barry, 1992), stenosis (Hatle et al., 1980; Olin et al., 1995; Schmidt et al., 1997), and occlusions (Moneta et al., 1992; Müller et al., 1995). It also has been used to determine vasoconstrictive and blood flow responses in cattle (Aiken et al., 2007; 2009b) and sheep (Aiken et al., 2011) to ergot alkaloids, and was performed with steers to quantify artery lumen area and blood flow responses to heat and cold challenges (Kirch et al., 2008). Color doppler ultrasonography has potential use as a diagnostic or research tool in identifying and quantifying aberrant constriction caused by ergot alkaloids or other toxicants. This chapter will discuss: 1) blood flow aspects of thermoregulation in livestock, 2) effects of ergot alkaloids on blood flow and thermoregulation and, 3) procedures and sources of error in using Doppler ultrasonography as a research tool in evaluating vasoconstrictive responses in livestock exposed to ergot alkaloids.

\section{Vascular control of blood flow for regulating core body temperature}

Blood flow is necessary for effective thermoregulation in all mammals. Core body temperature is maintained and stabilized through constriction or dilation of vasculature to control blood flow in peripheral tissues for the regulation of heat dissipation from capillary beds in the skin (Chotani et al., 2000; Johnson \& Kellogg, 2010). Excessive declines in core body temperature during cold ambient temperatures are controlled by vasoconstriction of blood flow that reduces heat transfer in the skin, whereas increases in core body temperature during warm ambient temperatures are mitigated through vasodilation to increase heat transfer (Chotani et al., 2000). During heat stress, there is decreased activity by sympathetic vasoconstrictor nerves and increased activity by a sympathetic cutaneous vasodialator nervous system (Johnson and Proppe, 1996). Expansion of the luminal area of blood vessels delivering blood flow to the skin during heat stress also provides the volume of water needed to drive sweating for evaporative cooling of the skin (Gagge and Gonzalez, 1996).

Blood flow rate is a function of cross-sectional luminal area of the vessel and flow velocity, with vessel luminal area having the greatest influence on flow rate. Based on Poiseuille's Law, volume flow rate $(\mathrm{mL} / \mathrm{min}$.) is directly proportionate to the fourth power of the radius of the cross-section of the vessel's lumen. Carter (2000) noted that a $10 \%$ decrease in radius of a tube under steady state conditions will reduce flow rate by approximately $35 \%$. Constriction and dialation of arteries and veins are mediated in response to hot or cold 
environments by endogenous biogenic amines: primarily serotonin, norepinephrine, and epinephrine (Johnson and Proppe, 1996; Strickland et al., 2011).

\section{Ergopeptnes and their effects on vascular circulation}

Ergopeptines are ergot alkaoids that are produced by an endophyte (Neotyphodium coenphialum) that infects tall fescue plants (Bacon, 1995), and by the N. lolii endophyte that infects perennial ryegrass (Easton \& Tapper, 2005). Although the endophyte that infects perennial ryegrass produces small amounts of ergot alkaloids that can induce vasoconstriction (Aiken et al., 2011), it is its production of lolitrem B that causes ryegrass staggers cattle and sheep which is of greater concern (Fletcher and Harvey, 1981). Livestock exhibiting staggers are incapacitated due to tremors, but the malady also affects animal performance (Siegel et al., 1985). All plant parts of tall fescue and perennial ryegrass contain ergot alkaloids, but alkaloid concentrations differ among plant parts. Rottinghaus et al. (1991) determined the ranking of plant parts from highest to lowest ergot alkaloid concentrations is seed, stem, leaf sheath, and leaf blade. There is a distinction between the mutual relationships between the wild-type, toxic endophytes that infect naturalized populations of tall fescue and perennial ryegrass and non-ergot alkaloid producing novel endophytes that are artificially infected into commercially released cultivars of each grass (Bouton et al., 2002). Claviceps spp. also produce ergot alkaloids, but fungal colonization and alkaloid concentrations are restricted to the seed or grain (Bandyopadhyay et al., 1998).

Ergovaline has been proposed as the likely causal agent in the fescue toxicosis syndrome (Lyons et al, 1986). In vitro electromyograph studies have reported ergovaline to cause contractile responses of bovine uterine and umbilical arteries (Dyer, 1993), rat tail and guinea pig iliac arteries (Schoning, et al., 2001), and lateral saphenous weins of cattle (Klotz et al., 2007). Klotz et al. (2007) reported similar contractile responses between ergovaline and ergotamine, with contractile responses being initiated at $1 \times 10^{-8} \mathrm{M}$ concentrations for both ergopeptines. An earlier experiment by Klotz et al. (2006) determined a weak in vitro contractile response of the lateral saphenous vein to lysergic acid (a structurally simpler ergot alkaloid (reviewed by Strickland et al., 2011) that did not mediate contraction until concentrations reached supraphysiological levels $\left(1 \times 10^{-4} \mathrm{M}\right)$. Dyer (1993) and Schoning et al. (2001) both showed that ergovaline elicited its contractile effects through activation of $5 \mathrm{HT}_{2 \mathrm{~A}}$ serotonergic receptors. However, in contrast to Dyer (1993) who showed that the $\alpha_{1}$-adrenergic receptor was not important in the contractile effects of ergovaline on the bovine uterine and umbilical arteries; Schoning et al. (2001) clearly demonstrated that the $\alpha_{1}$-adrenergic receptors were important to vascular regulation by ergovaline in their blood vessel models. Similar findings have been noted for other ergot alkaloids produced by both Neotyphodium and Claviceps spp. (reviewed by Strickland et al., 2009a, b; Strickland et al., 2011).

Although in vitro models are useful tools for investigating and identifying the modes by which the ergot alkaloids may effect vascular dysfunction, the data from these models must be interpreted with care until fully validated by in vivo models. Partial validation is provided by the results of earlier in vivo studies. Lewis and Gelfand (1935) demonstrated that ergotamine treatment of chickens resulted in cessation of blood flow to the comb and subsequent gangrene. They postulated that the gangrene developed as a result of endothelia damage. Shappell (2003) demonstrated that ergovaline was, in fact, directly cytotoxic to a 
number of cell types, including endothelial cells. Additional morphological changes and blood flow dysfunction of peripheral tissues in cattle have been reported (Walls and Jacobson, 1970; Julien et al., 1974; Williams et al., 1975), including: blood vessel congestion, perivascular hemorrhage, blood vessel distension, and thickened blood vessel walls with small lumens. Strickland et al. (1996), provided evidence, using bovine vascular smooth muscle cells in vitro, that the thickened blood vessel walls were likely the result of hyperplasia and not hypertrophy.

In addition to the noted effects in the peripheral vascular beds, Rhodes et al. (1991) reported ergot alkaloid induced in vivo constrictive responses in several vascular beds of steers. Using radiolabeled microspheres, steers fed diets with high ergot alkaloid concentrations (2.6 mg egovaline/ $\mathrm{kg} \mathrm{DM}$ ) had reduced blood flow to rib skin, cerebellum, duodenum, and colon, as compared to those fed low ergot alkaloid diets (< $0.05 \mathrm{mg}$ ergovaline $/ \mathrm{kg} \mathrm{DM})$. They also reported similar findings in sheep. The aforementioned in vivo studies have provided partial validation of the in vitro findings to date. Further, the in vitro data coupled with the in vivo findings support a strong role of the ergot alkaloids in vascular dysfunction. However, none of the aforementioned studies have been capable of studying, in real time, the effects of the ergot alkaloids on vascular function in the intact and unaltered animal. Color Doppler Ultrasonography offers the opportunity to do exactly that as is evidenced by recent publications (Aiken et al., 2007, 2009b, and 2011) concerning blood flow changes in cattle and sheep exposed to ergot alkaloids.

\section{Color Doppler ultrasonography in measuring vasoconstriction}

Color Doppler ultrasonography was introduced in the 1980s, but it was not until the 1990s that B-mode (two dimensional, gray scale) and color Doppler scans were combined as duplex images (Fig. 1) and used as a diagnostic or research tools in evaluating hemodynamics and increasing our knowledge of the characteristics and physiology of normal and abnormal blood flows. Color Doppler ultrasonography was used to evaluate hemodynamics and cross-sectional luminal areas of the cerebral artery in humans during

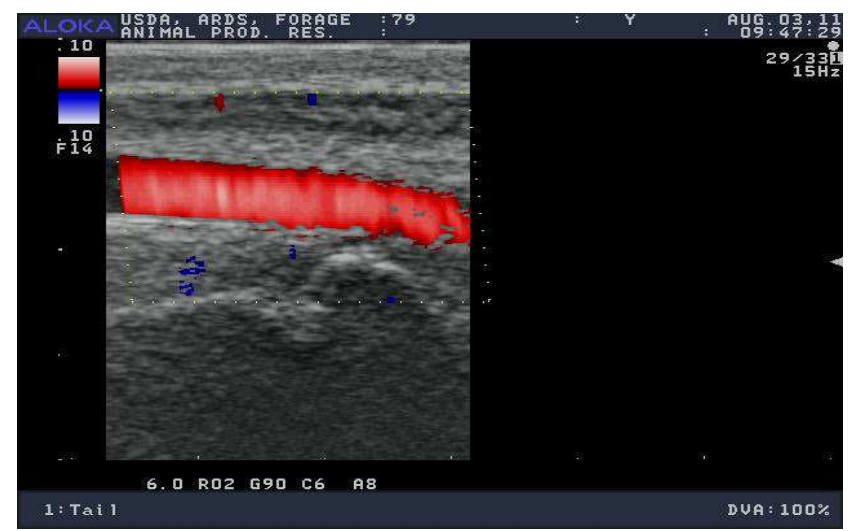

Fig. 1. A duplex image with B-mode image of a longitudinal section of the caudal artery of a heifer combined with color Doppler to exhibit blood flow. 
hypoxia and hypercapnia (Poulin and Robbins, 1996). Wendelhag et al. (1991) utilized Bmode ultrasonography to measure carotid luminal and plaque areas in humans. Doppler spectra have provided estimates of blood flow characteristics in arteries of the dog (Lee et al., 2004) and horses (Raisis et al., 2000; Hoffman et al., 2001). Recently, color doppler ultrasonography was performed in evaluating vasoconstriction and blood flow responses to ergot alkaloid exposure in cattle (Aiken et al. 2007; 2009b) and sheep (Aiken et al., 2011). Therefore, the technology has been utilized to acquire baseline measures of normal flood flow characteristics and assessing vascular constriction as a factor of abnormal blood flow.

It is beyond the scope of this chapter to provide a detailed description of the mechanics and physics associated with color Doppler ultrasonography, but some basic fundamentals are necessary for understanding the procedures and potential errors when using the technology. Basically, the transducer transmits a frequency of ultrasonic sound waves ( 1 to $30 \mathrm{MHz}$ ) through tissues and, depending on the densities of the tissues the ultrasound beam contacts, a portion of the waves pass through a particular tissue and the remainder is reflected. Piezoelectric crystals in the transducer transmit and receive wave frequencies and the ultrasound unit compiles and converts the wave energy to electrical energy. There is a progressive loss of acoustic energy as ultrasonic beams passes through tissues, which is referred to as attenuation. Attenuation is the decrease in the intensity of returning sound waves as ultrasonic beams are transmitted into deeper tissues. Amount of attenuation, measured in $\mathrm{dB} / \mathrm{cm}$, is dependent on depth of ultrasonic beam, density of the tissue the beam passes through, and the frequency of the transmitted beam (Sites et al., 2007). Gain settings (i.e., separate settings for B-mode, color Doppler, and Doppler spectra) affect sensitivity. Amplitude and velocity information of the transmitted versus received frequencies are used to compute and delineate anatomical structures viewed in B-mode images, blood flow identification, and velocity within the sample volume cursor placed in the real-time color Doppler images.

There are two types of transducers used in color Doppler ultrasonography, continuous- and pulse-wave Doppler transducers. Continuous-wave transducers use 2 crystal units to continuously transmit and receive ultrasound waves. They can accurately measure a wide range of flow velocities within a vessel, but lacks an ability to control location of measurements within the vessel lumen. Most Doppler ultrasound units use pulsed-wave transducers that alternate groups of crystals in transmitting and receiving ultrasound wave in pulses to provide Doppler shift data from a specified area within the vessel lumen. This specified area, referred to as the sample volume, is set by the operator. Ultrasonic beans also can be angled with curvilinear and linear phased array transducers. For pulse Doppler scanning, the same mechanisms apply as with B-mode scans, but the sample volume cursor is placed in a B-mode image of a longitudinally scanned vessel and within the color generated by blood flow (red for flow towards the transducer and blue for flow away from the transducer). Doppler spectra derived from blood flow within the sample volume cursor can be automatically or manually traced for a given cardiac cycle to measure systolic velocity, end diastolic velocity, mean velocities, and resistance and pulsatility indices using algorithms in the computer of most Doppler ultrasound units. Most Doppler ultrasound units also will provide measures of heart rate, time, and acceleration. The longitudinal color Doppler image and Doppler spectra are typically combined (Fig. 2), with the color Doppler scan being utilized for placement of the sample volume cursor for the observed Doppler spectra. 


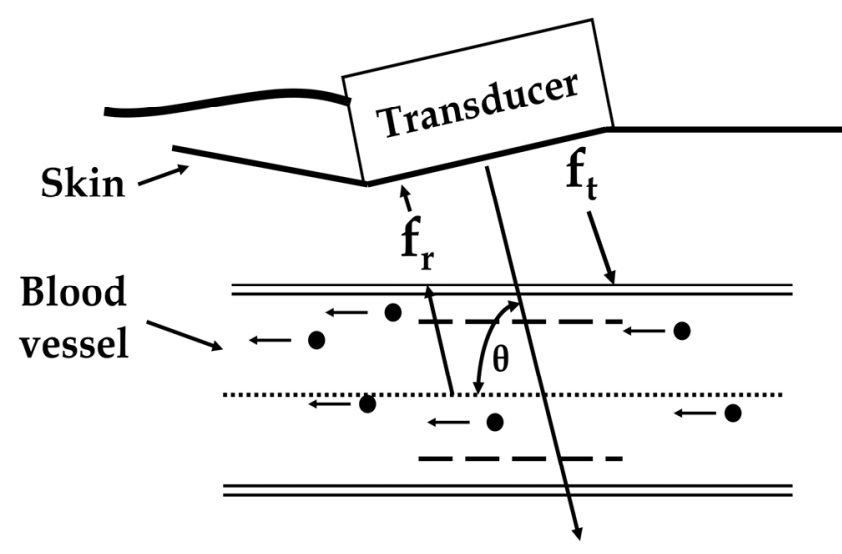

Fig. 2. Transmission (ft) and receiving (fr) ultrasound beams for the detection of Doppler signals from blood flow. The Doppler angle, $\theta$, is the angle between the directions of blood flow and the beam. Space within the dashed lines represents the sample volume (Adapted from Zagzebski, 2000).

Blood flow velocity is determined by calculating Doppler Frequency $\left(f_{\mathrm{D}}\right)$ :

$$
f_{\mathrm{D}}=2 f_{\mathrm{t}} \mathrm{v} \cos \theta / \mathrm{c}
$$

where $f \mathrm{t}$ is the transmitted frequency, $f_{\mathrm{r}}$ is the received frequency, $\mathrm{v}$ is the blood flow velocity, $\theta$ is the Doppler angle between the axis of the ultrasound beam and the direction of flow, and $\mathrm{c}$ is the speed of sound. The Doppler effect allows the calculation of velocity of a moving object as the frequency of sound waves generated by the object increases as it moves from a far to a near distance. Calculation of blood flow velocity is not possible if the ultrasound beam is parallel with blood flow (i.e., $\theta=90^{\circ}$ ). Angling of the ultrasonic bean must be done through angling of the transducer or using the beam steering with phased array transducers.

Pulse-wave transducers are designed to receive frequencies of scattered sound waves bounced from moving particles (e.g., hemoglobin) within the sample volume cursor of the targeted vessel (Fig. 3). Cross-sectional color Doppler images can be used to trace luminal areas of vessels and combined with blood flow velocities derived from Doppler spectra from a longitudinal image of the vessel to calculate blood flow rate (mean velocity $X$ cross-sectional luminal area). Luminal areas determined from cross-sectional scans of vessels can be used to evaluate contractile responses of smooth muscle within artery and vein walls to environmental conditions, pharmaceuticals, or toxicants. Therefore, duplex imaging of B-mode and color Doppler ultrasound images has provided a tool for conducting either diagnoses or scientific research in real time that is noninvasive, and can be repeatable and objective by following good scanning technique and interpretation procedures. 


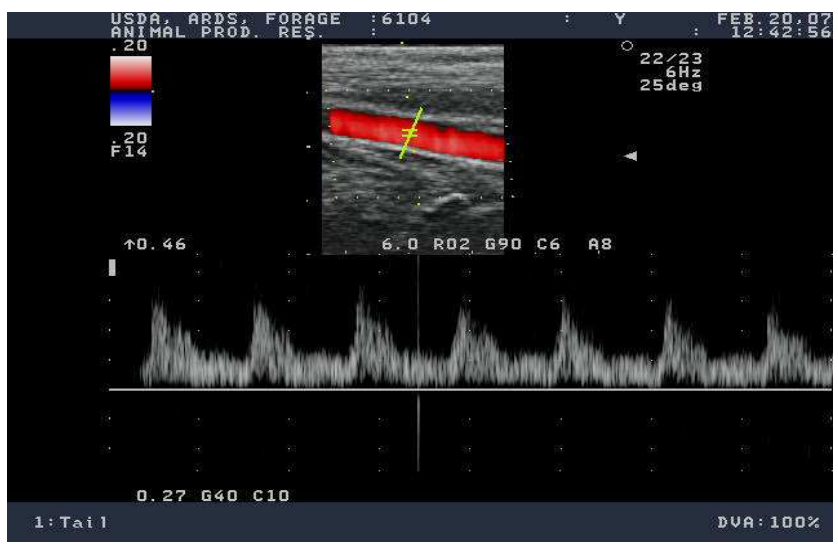

Fig. 3. Duplex image of a longitudinal scan of the median caudal artery of a heifer showing the sample volume cursor (upper image) and the Doppler spectra (lower image).

\subsection{Doppler imaging the vasculature of livestock}

Determinations of constriction and blood flows in small arteries or veins are possible with Doppler ultrasonography if comparisons are made between with and without toxicant treatment groups of animals, or between baseline measures when animals are without toxicant exposure versus measures after exposure to toxicants. Walls of small veins possess smooth muscle and endothelium at the vessel intima that contain biogenic amide receptors; therefore, veins will elicit a vasoconstrictrive response to ergot alkaloids and facilitate a comparison between animals with and without exposure to ergot alkaloids. Unfortunately, elasticity of veins negates obtaining measures of blood flow resistance, which is valuable information on down-flow resistance. Small arteries possess thicker walls and layers of smooth muscle and are positioned upstream from capillary beds, which facilitate measurement of blood flow resistance, a relevant blood flow characteristic. Aiken et al. (2011) did not observe constriction in the carotid arteries of lambs over a 9-d period of grazing perennial ryegrass infected with a novel endophyte that produced ergovaline, but the carotid showed linear increases in pulsatility, a measure of blood flow resistance (Petersen et al., 1997). It was concluded that constriction of cranial arteries were the source of resistance detected in the carotid arteries.

Emphasis on blood flow to peripheral tissues facilitates use of high frequency ( $\geq 5 \mathrm{MHz}$ ) transducers that will provide high resolution imaging of vessels at low depths from the transducer. Hemodynamics can be studied for vessels less than 2 to $3 \mathrm{~cm}$ from the skin surface and supplying blood to the tissues of the extremities. Cross-sectional images of the medial caudal artery (Fig. 4) of cattle has been imaged at the base of the tail to evaluate constrictive responses of the artery to ergot alkaloids (Aiken et al., 2007; 2009b; Kirch et al., 2008). For sheep, flow through the caudal artery is affected from the docking of tails and of questionable reliability, but cross-sectional images of the posterior auricular artery (Fig. 5) that supplies blood to the ear can reliably be used for assessing vasoconstriction ( Aiken et al., 2011). Cross-sections of the medial palmer artery of the forelimb also have been imaged (Fig. 6; unpublished data collect by K. McDowell; Dept. of Veterinary Sciences; University of Kentucky). 


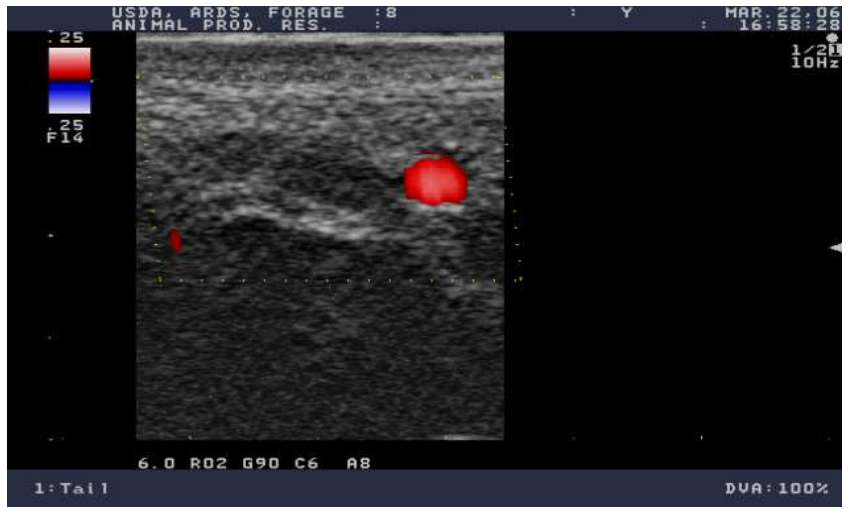

Fig. 4. Cross-sectional image of the medial caudal artery in a heifer calf.

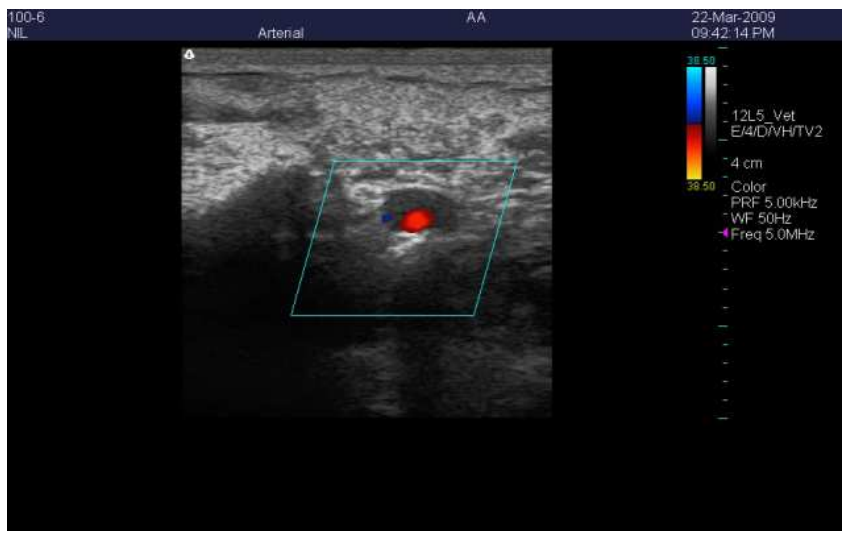

Fig. 5. Cross-sectional image of the right auricular artery of a ewe lamb.

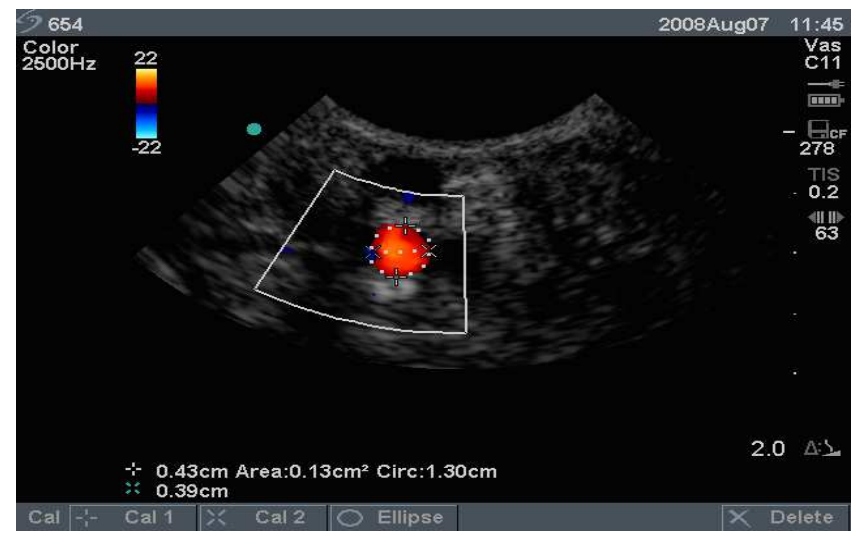

Fig. 6. Cross-sectional image of the medial palmer artery of a mare. 
Other vessels can be scanned, but decisions of which vessels to study in livestock animals should be partly based on ease and safety for a particular image site. Imaging of larger livestock that must be handled in chutes (i.e., pastured animals with minimal exposure to humans) or stanchions should be restricted to exposed upper regions. Ultrasounding vessels in legs should be restricted to haltered animals at ease with human contact because of the vulnerability to operator injury and equipment damage. Major arteries (e.g., aorta, carotid, mysenteric, etc.) and those supplying blood to major organs (e.g., hepatic, pulmonary, cerebral, etc.) can be studied to ascertain toxicant effects on organ function. These evaluations at greater tissue depths must be done with low pulse frequencies ( 2 to $5 \mathrm{Mhz}$ ) to obtain the needed resolution and with high end, high resolution ultrasound units. It is further recommended these studies be done with haltered, calm animals in controlled environments. Further, obese animals should be avoided because thick layers of subcutaneous adipose will cause interference in achieving high resolution with B-mode Doppler images taken at low frequencies (Pozniak, 2000).

Lumen areas of vessels can be traced from B-mode scans with or without color Doppler imaging (Fig. 7). Aiken et al. (2009a) concluded that artery luminal areas can be measured with similar precision by tracing the intima of connective tissue in the artery wall or the outer boundary of the color Doppler flow signal. Color Doppler imaging for measuring luminal area will require images depicting the maximum flow signal which will coincide with peak systole. These images can be identified using the cine memory of the ultrasound unit. There are two methods of imaging color blood flow. Color Doppler uses the Doppler frequency shift to detect flow within the vessel and shifts the color shade from dark to light as frequency and velocity increases. Power Doppler imaging uses the power or intensity of the Doppler signal to show differences in blood flow velocities within a vessel. Power Doppler is generally more sensitive than color Doppler in detecting blood flow. Without color Doppler, luminal areas should be at certain points of a cardiac cycle (e.g., peak systole or end diastole) identified using Doppler spectra. The ultrasound beam should be perpendicular to blood flow when measuring cross-sectional luminal areas, as deviations from perpendicular will enlarge luminal areas. A $10^{\circ}$ departure from perpendicular will increase luminal area by approximately $5 \%$. Lumen area diameter also can be measured from longitudinal images of vessels, but the ultrasonic beam must be centered over the vessel. Departures from this center point will be biased towards smaller luminal areas.

As previously discussed, Doppler spectra are derived from blood flow within the sample volume cursor or gate, which can be adjusted to various sizes. A small sample volume can be used and positioned in the middle of the vessel, which has the highest velocity with luminar blood flow; however, inconsistent positioning with this approach can inflate between image variations. A wider sample volume can provides a measure of mean flow velocity within the vessel and result in less between-image variability. The sample volume should be consistent width between animals in a study to reduce this source of variation.

Aliasing of color displays and Doppler spectra can occur when using pulse Doppler. Aliasing is caused by a wraparound of the display, with high velocity flow moving towards 


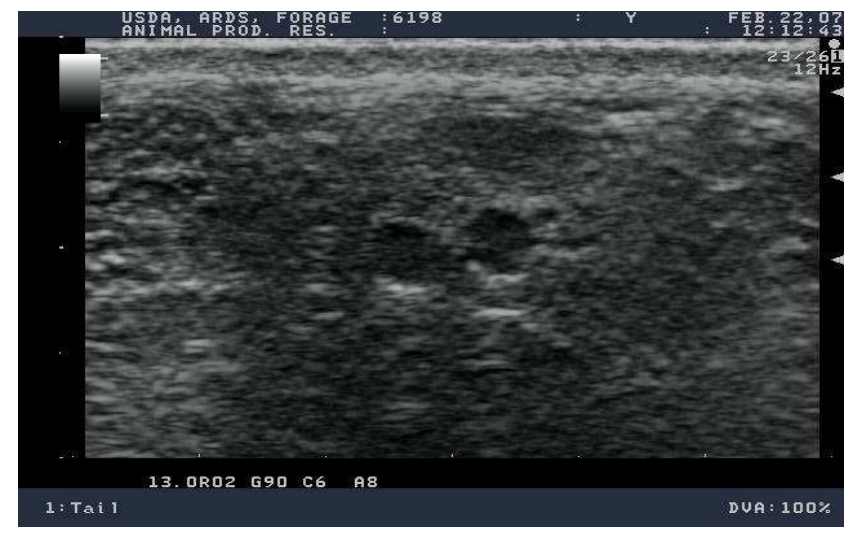

(a)

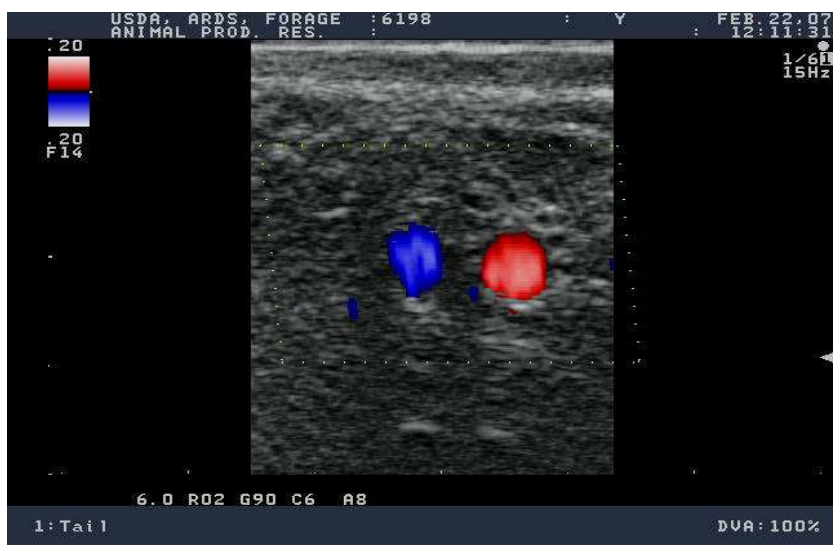

(b)

Fig. 7. Cross-sectional B-mode images of the medial caudal artery (vessel on right) and vein (vessel on left) in a heifer calf, without (a) or with (b) color Doppler.

the probe (i.e., expected to be red) appearing that is moving away from the probe (Fig. 8; i.e., displayed to be blue). This aliasing can be eliminated by increasing the pulse repetition frequency, which increases the color flow velocity scale. Aliasing also occurs with Doppler spectra, with the spectra of high velocity blood flow being converted to reverse flow spectra (Fig. 9). As with the color display, the pulse repetition frequency can be increased to increase the flow velocity scale. The operator also can reduce the spectra baseline down until the spectra represents flow in one direction. 


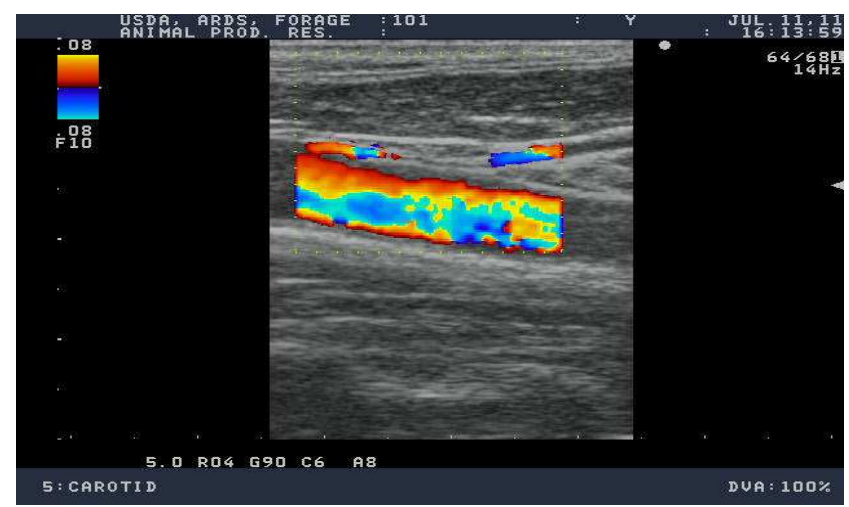

Fig. 8. Aliasing of the flow display with a color Doppler image

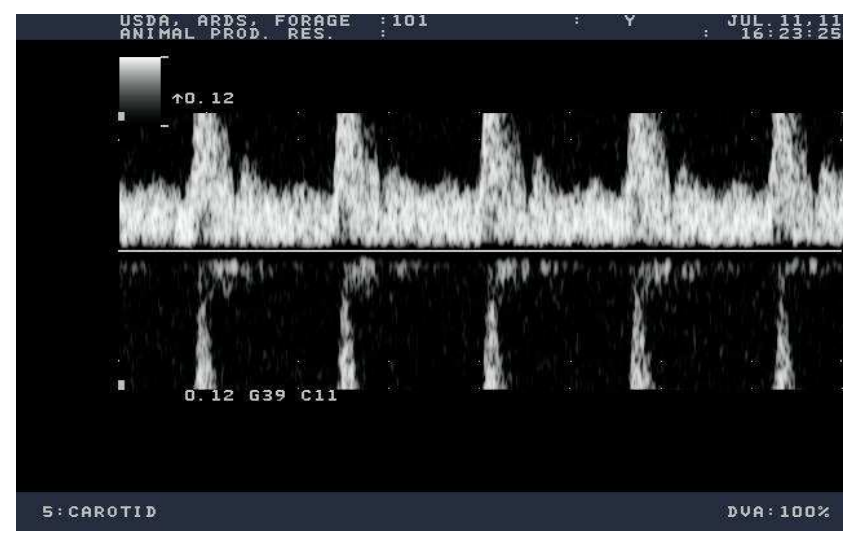

Fig. 9. Aliasing of the Doppler spectra.

\subsection{Using serial images to determine sensitivities and response to toxicants}

Direct comparisons in luminal vessel areas and blood flow characteristics can be made with color Doppler ultrasonography between groups of animals that are with or without exposure to toxicants. Of greater importance, however, can be in measuring vascular sensitivity to toxicants. The research tool has successfully measured vascular sensitivity to ergot alkaloids in cattle (Aiken et al. 2007; 2009b) and sheep (Aiken et al., 2011), and to determine vascular recovery of sheep after being switched from toxic endophyte-infected pastures of perennial ryegrass to endophyte-free ryegrass (Aiken et al., 2011). Following an initial feeding of a diet containing $0.8 \mathrm{mg}$ ergovaline $/ \mathrm{kg}$ dry matter to heifers, Aiken et al. (2007) observed a tendency for a vasoconstrictive response by the caudal artery in 4 hours. A similar experiment that fed treatment diet concentrations of $0,0.2$, and $0.8 \mathrm{mg}$ ergovaline $/ \mathrm{kg}$ dry matter to heifers determined there were vasoconstrictive responses by the caudal artery in 27 hours for the $0.8 \mathrm{mg}$ ergovaline/ $\mathrm{kg}$ dry matter diet concentration, and in 51 hours for the $0.4 \mathrm{mg}$ ergovaline $/ \mathrm{kg}$ DM dry matter. 
Serial imaging also can be used to determine the extent and persistence of the vascular constriction response to toxicants. Following a reduction in luminal area and blood flow rate in heifers consuming diets consuming 0.4 or $0.8 \mathrm{mg}$ ergovaline/ $\mathrm{kg} \mathrm{DM}$, Aiken et al. (2007) reported adjustments in luminal area and blood flow velocity to original baseline measures, taken when heifers were on a $0 \mathrm{mg}$ ergovaline/ $\mathrm{kg}$ DM diet concentration adjustment diet, as air temperatures increased (Fig. 10). However, animals on control diets have shown greater variation in blood flow than those on treatment diets containing ergot alkaloids. Aiken et al. (2007; 2009b) concluded there was greater variation in caudal artery luminal areas and blood flow rates among control cattle compared to those on treatment diets (refer to standard error bars in Fig. 10), making it necessary to evaluate deviations from baseline measures for determine alkaloids effects. Low variation in caudal artery luminal areas among cattle on the treatment diet was suggested to be associated with persistent vasoconstriction causing an inability to adjust their vasculature to changes in ambient temperature.

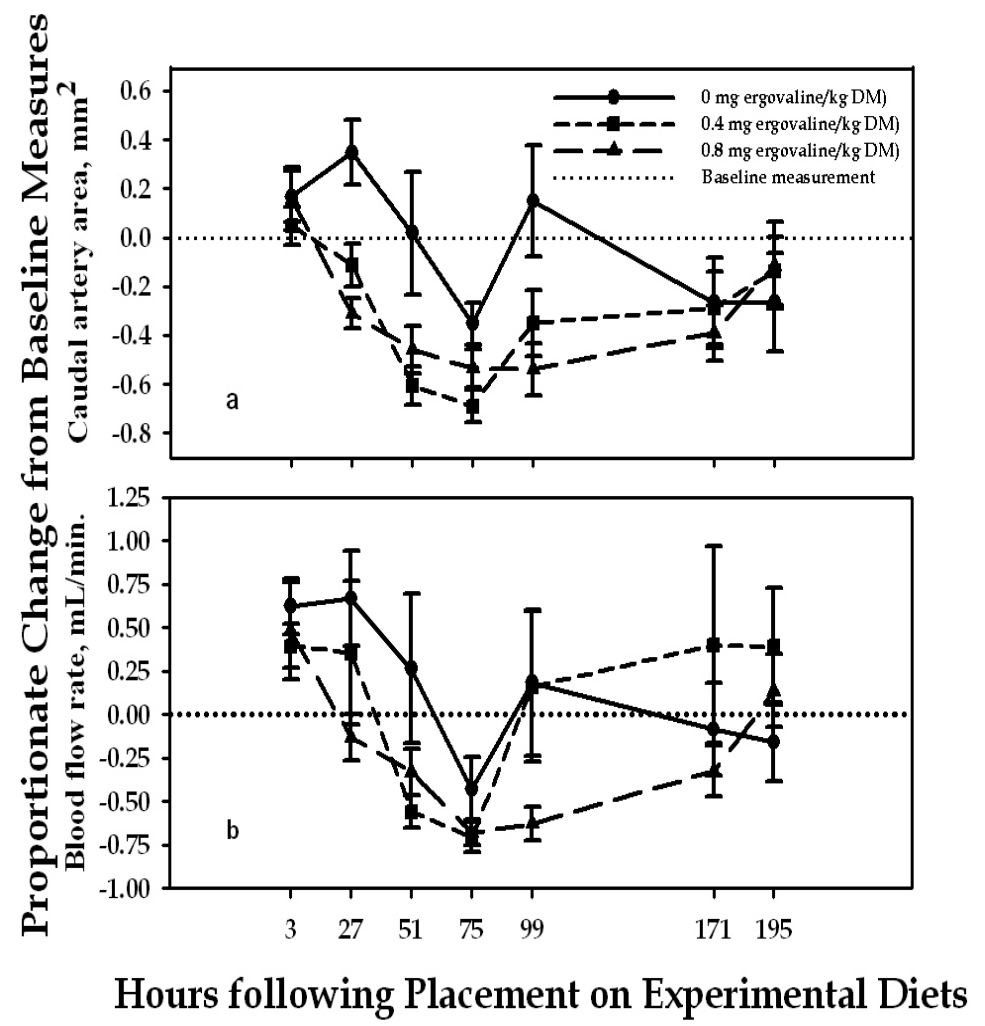

Fig. 10. Trends in luminal area of the caudal artery (a) and blood flow rate through the caudal artery (b) in heifer calves flowing placement of cattle on experimental diets $(0,0.4$, or $0.8 \mathrm{mg}$ ergovaline/kg DM) (from Aiken et al., 2009b).

Aiken et al. (2011) used color Doppler ultrasound to determine constriction of the auricular and carotid arteries in ewe lambs after they were switched from endophyte-free perennial 
ryegrass to ryegrass infected with a novel endophyte that produces high concentrations of ergovaline. A linear decline in luminal area of the auricular artery was observed over a 9day after grazing was initiated. Lambs also were switched from AR6 novel endophyte ryegrass to endophyte-free pasture. Over the 9 days, luminal area of the auricular artery increased linearly and pulsatillity indices for the carotid decreased linearly. There was relaxation of the vasculature from alkaloid clearance, but a longer duration of data collection was needed to determine the time needed for complete clearance of alkaloids from the vasculature.

\subsection{Special considerations in animal handling}

Accuracy and precision of measurements of blood flow characteristics in livestock are vastly improved if the measurements are collected in controlled environments with halter broke animals that are at ease with human contact. Furthermore, controlled diets fed in pens with know concentrations of toxicants will be necessary if research objectives are focused on determining sensitivities and strength of response to the toxicant. Blood flow measurements for pastured animals with minimal contact with humans will be affected by animal nervousness (e.g. increases in heart rate). However, measurements from ultrasound images are possible in uncontrolled environments and without halter-broke animals if control animals (e.g., animals grazing toxicant-free pastures) are measured and special animal handling procedures are followed.

Pastured cattle are typically handled in squeeze chutes with narrow alleys (Fig. 11) leading to the chute. Cattle are gregarious and individuals become nervous when singly separated from the group. When imaging cattle in squeeze chutes, the time individuals spend in the alley prior to being imaged should be minimized. Rather than crowding the alley, cattle should be placed in the alley in groups of three, with subsequent groups of three being placed in the alley such that an animal is not alone in the alley. Once in the chute, the sides of the chute should be reduced to not squeeze the animal to a point of discomfort, but reduce the area containing the animal. Potential nervousness of cattle worked in chutes makes it difficult to image cranial regions; therefore, imaging is better done if restricted to caudal regions (e.g., caudal artery or vein). The area should also be as quiet of sound, as possible, to minimize animal startling and raising of heart rates. Further, any sample collections (e.g., blood) or measurements (e.g., rectal or skin temperatures) should be done after imaging.

Imaging of horses can typically be done in stanchions with those that are haltered and at ease with humans (Fig. 12). Sheep and goats tend to also be gregarious, but do not present the same degree of nervousness as cattle. Small ruminants can be worked on cradles (Fig. 13) and provide opportunities to reliably image the cranial vessels (Aiken et al., 2011).

Imaging animals in an uncontrolled environment requires that images be collected over a period of time during the day with minimal changes in air temperature and humidity (Kirch et al., 2008). Imaging quality also is a major consideration in providing reliable interpretations and measures. Time must be taken to correctly place tranducers over the vessels, with sufficient gain and focus settings to optimize B-mode and color Doppler images, and Doppler spectra, Therefore, time of day and time necessary to collect quality 
images must be considered. For each animal, five images for each cross-sectional and longitudinal section should be collected at each scanning session. A minimum of 5 animals per treatment should be scanned to account for the variation in blood flow characteristics between animals.

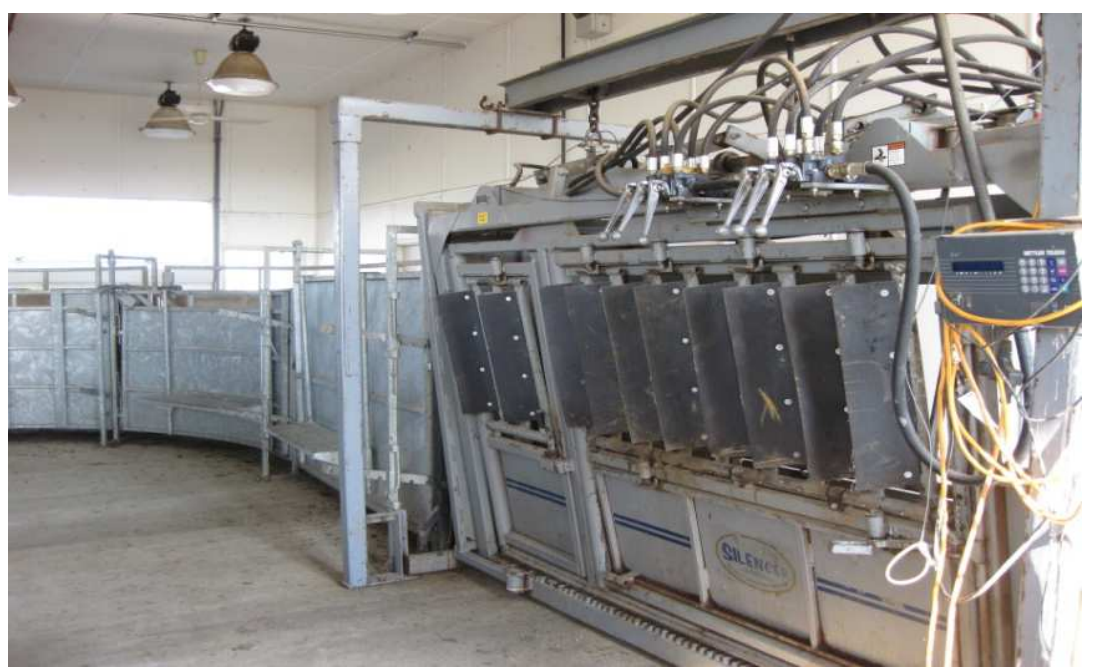

Fig. 11. Squeeze chute and alley used for to retrain cattle.

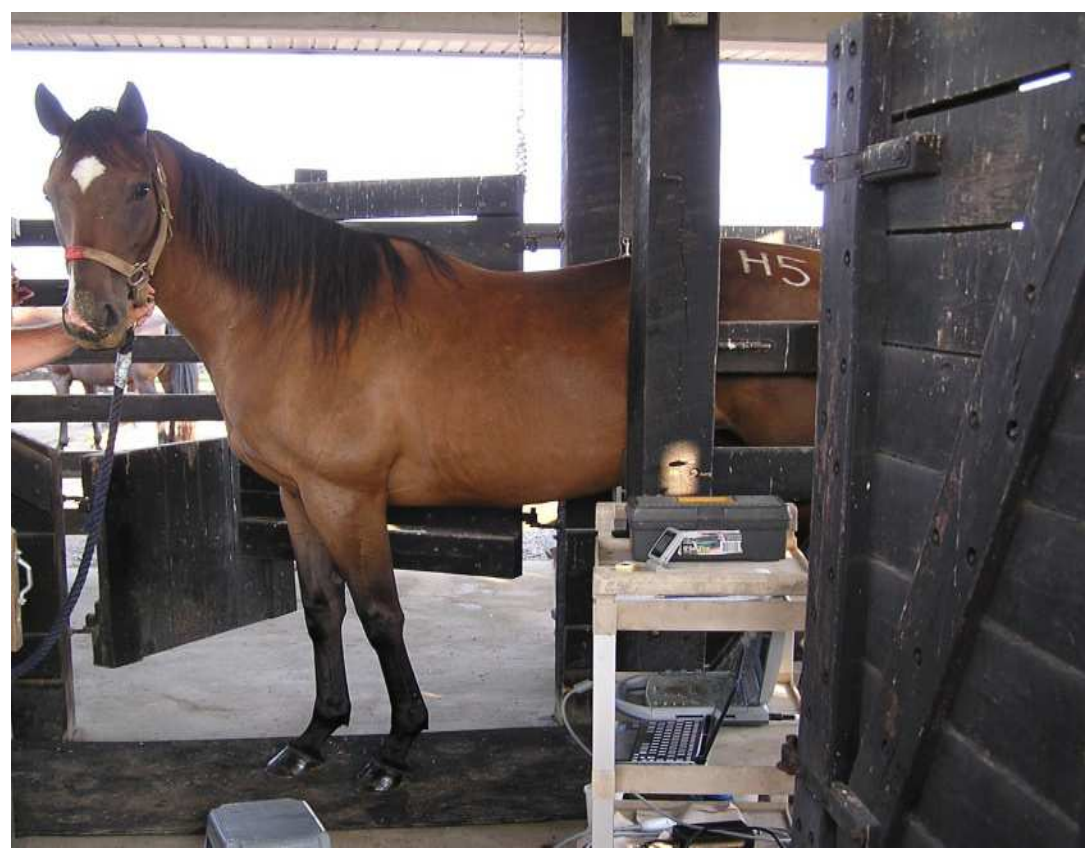

Fig. 12. A haltered horse in a wooden stanchion. 


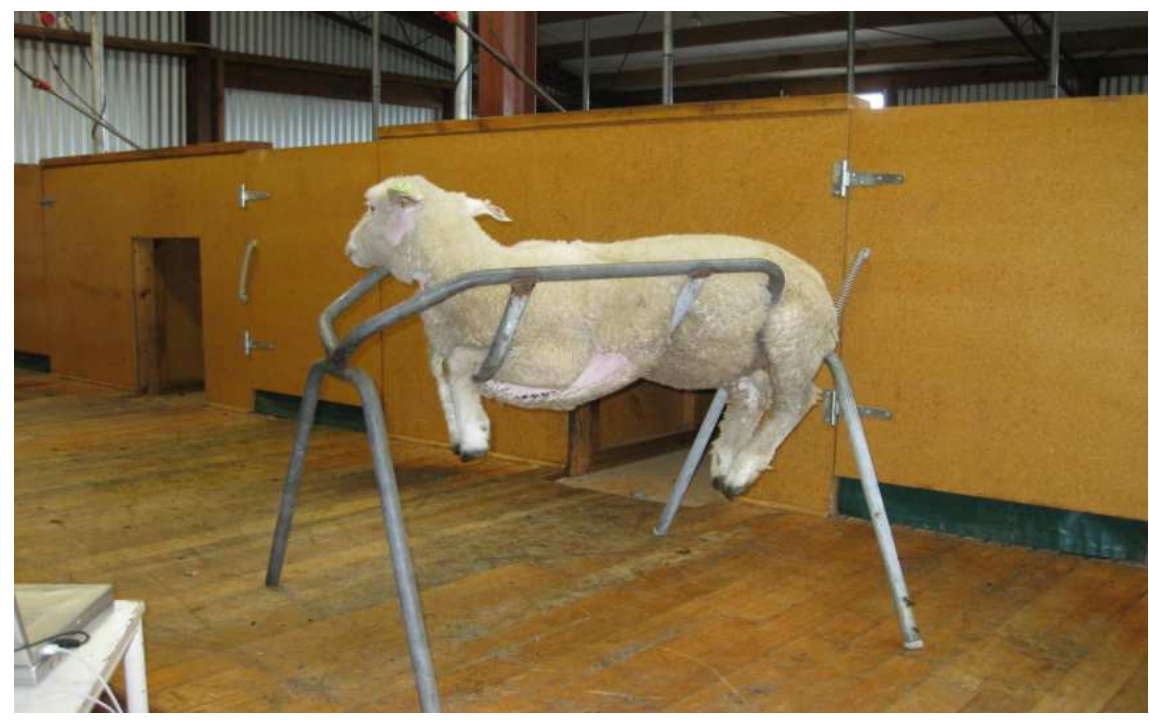

Fig. 13. Cradle used to restrain sheep.

\section{Summary}

Color Doppler ultrasonography is a non-invasive procedure that is routinely used to assess normal and abnormal blood flow in human and veterinary medicines. It also has application as a research tool in determining vascular responses to toxicants that can effect the vasculature. These studies are ideally performed in controlled environments with animals that are at ease with human contact and do not require restraint that can cause discomfort. However, reliable measures can be collected with pastured animals with minimal human contact if control animals with no exposure to toxicants are measured for comparisons with treatment animals, and special handling procedures are employed to reduce animal nervousness and tension effects on vasculature blood flow.

\section{References}

Aiken, G.E., Sutherland, B.L., \& Fletcher, L.R. (2011). Haemodynamics of lambs grazing perennial ryegrass (Lolium perenne L.) either infected with AR6 novel, wild-type endophyte, or endophyte-free. New Zealand Veterinary Journal, Vol. 59, (June 2011), 179-184, ISSN 0048-0169

Aiken, G.E., Kirch, B.H., Strickland, J.R., Bush, L.P., Looper, M.L., \& Schrick, F.N. (2007) Hemodynamic responses of the caudal artery to toxic tall fescue in beef heifers. Journal of Animal Science, Vol. 85, (September 2007), 2337-2345, ISSN 0021-8812

Aiken, G.E., Klotz, J.L., Kirch, B.H., Strickland, J.R., \& Boykin, D.L. (2009a). Technical note: Comparison between two tracing methods with ultrasonography to determine lumen area of the caudal artery in beef cattle. Journal of Animal Science, Vol. 87, (January 2009), 371-374, ISSN 0021-8812 
Aiken, G.E., Strickland, J.R., Looper, M.L., Bush, L.P., \& Schrick, F.N. (2009b) Hemodynamic are altered in the caudal artery of beef heifers fed different ergot alkaloid concentrations. Journal of Animal Science, Vol. 87 (February 2009), 21422150, ISSN 0021-8812.

Aldrich, C.G., Rhodes, M.T., Miner, J.L., Kerley, M.S., \& Paterson, J.A., (1993). The effects of endophyte-infected tall fescue consumption and use of a dopamine antagonist on intake, digestibility, body temperature, and blood constituents in sheep. Journal of Animal Science, Vol. 71, (January 1993), 158-163, ISSN 0021-8812

Al-Haidary, A., Spiers, D.E., Rottinghaus, G.E., Garner, G.B., \& Ellersieck, M.R. (2001). Thermoregulatory ability of beef heifers following intake of endophyte-infected tall fescue during controlled heat challenge. Journal of Animal Science, Vol. 79, (July 2001), 1780-1788, ISSN 0021-8812

Bandyopadhyay, R., Frederickson, D.E., McLaren, N.W., Odvody, G.N., \& Ryley, M.J. (1998). Ergot: A new disease threat to sorghum in the Americas and Australia. Plant Disease, Vol. 82, (April 1998), 356-367, ISSN 0191-2917

Bacon, C.W. (1995) Toxic endophyte-infected tall fescue and range grasses: Historic perspectives. Journal of Animal Science, Vol. 73, (March 1998), 861-870, ISSN 00218812

Blaney, B.J., McLennan, S,R, Kidd, J.F., Connell, J.A., McKenzie, \& Downing, J., Jr. (2011). Effect of sorghum ergot (Claviceps Africana) on the performance of steers (Bos Taurus) in a feedyard. Animal Production Science, Vol. 51, (January 2011), 156-166, ISSN 1836-0939

Blaney, B.J., Molloy, J.B., \& Brock, I.J. (2009). Alkaloids in Austraiian rye ergot (Claviceps purpurea) sclerotia: Implications for food and stockfeed regulations. Animal Production Science, Vol. 49, (October 2009), 975-982, ISSN 1836-0939

Bouton, J.H., Latch, C.G., Hill, N.S., Hoveland, C.S., \& Wood, D.T. (2002). Reinfection of tall fescue cultivars with non-ergot alkaloid-producing endophytes. Agronomy Journal, Vol. 94, (May 2002), 567-574, ISSN 0002-1962

Browning, R., Jr., Leite-Browning, M.L., Smith, H.M., \& Wakefield, T., Jr. (1998). Effect of ergotamine and ergonovine on plasma concentrations of thyroid hormones and cortisol in cattle. Journal of Animal Science 76, (June 1998) 1644-1650, ISSN 0021-8812

Browning, R., Jr., Thompson, F.N., Sartin, J.L., \& Leite-Browning, M.L. (1997) Plasma concentrations of prolactin, growth hormone, and luteinizing hormone in steers administered ergotamine or ergonovine. Journal of Animal Science, Vol. 75, (March 1998), 796-802, ISSN 0021-8812

Bush, L.P., \& Fannin, F.F. (2009). Alkaloids, In: Tall Fescue for the Twenty-First Century. Fribourg, H.A., Hannaway, D.B., \& West, C.P. (Eds.) 229-249, ASA, CSSA, SSSA. ISBN 978-0-89118-172-9, Madison, WI

Carter, S.A. (2000). Hemodynamic considerations in peripheral vascular and cerbrovascular disease, In: Introduction to Vascular Ultrasonography, Zwiebel, W.J. (Ed.), 3-16. W.B. Saunders Co., ISBN 0-7216-6949-2, Philadelphia, PA

Chestnut, A>B. Bernard, J.K., Harstin, J.B., \& Reddick, B.B. (1992). Performance of growing lambs fed Acremonium coenophilum infested tall fescue (Festuca arundinacea Schreb.) hay. Small Ruminant Research, Vol. 7 (February 1992), 9-19, ISSN 0921-4488

Chotani, M.A., Flavahan, S, Mitra, S., Danunt, D., \& Flavahan, N.A. (2000). Silent a2cadrenergic receptors enable cold-induced vasoconstriction in cutaneous arteries. 
American Journal of Heart and Circulatory Physiology, Vol. 278, (April 2000), 10751083, ISSN 0363-6135

Cross, D. L., Redmond, L. M., \& Strickland, J. R. (1995). Equine fescue toxicosis: Signs and solutions. Journal of Animal Science, Vol. 73, (March 1995), 899-908, ISSN 0021-8812

Dyer, D. C. (1993). Evidence that ergovaline acts on serotonin receptors. Life Sciences, Vol. 53 (July 19913), PL223-PL228, ISSN 0024-3205

Fletcher, L.R., \& Harvey, I.C. (1981). An association of a Lolium endophyte with ryegrass staggers. New Zealand Veterinary Journal, Vol. 29, (October 1981), 185-186, ISSN 0048-0169

Gagge, A.P., \& Gonzalez R.R. (1996). Mechanisms of heat exchange: Biophysics and physiology, In: Handbook of Physiology, Section 4: Environmental Physiology, Fregley M.J. \& Blatteis, C.M. (Eds.), 45-83, Oxford University Press, ISBN 0-19-509174-4, New York, NY

Hannah, S.M., Paterson, J.A., Williams, J.E., Kerley, M.S., \& Miner, J.L. (1990). Effects of increasing levels of endophyte-infected tall fescue seed on diet digestibility and ruminal kinetics in sheep. Journal of Animal Science, Vol. 68, (June 1990), 1693-1701, ISSN 0021-8812

Hatle, L., Angelsen, B.A., \& Tromsdale, A. (1980). Non-invasive assessment of aortic stenosis by Doppler ultrasonography. British Heart Journal, Vol. 43, (March 1980), 284-292, ISSN 0007-0769

Hemken, R.W., Boling, J.A., Bull, L.S., Hatton, R.H., Buckner, R.C., \& Bush, L.P. (1981) Interaction of environmental temperature and anti-quality factors on the severity of summer fescue toxicosis. Journal of Animal Science, Vol. 73, (April 1981), 1954-1961, ISSN 0021-8812

Hoffman, K.L., Wood, A.K.W.,Griffiths, K.A., Evans, D.L., Gill, R.W., \& Kirby, A.C. (2001) Doppler sonographic measurements of arterial blood flow and their repeatability in the equine foot furing weight bearing and non-weight bearing. Research in Veterinary Science, Vol. 70, (June 2001), 199-203, ISSN 0034-5288

Johnson, J.M. \& Kellogg, D.L., Jr. (2010). Local thermal control of the human cutaneous circulation. Journal of Applied Physiology, Vol. 109, (October 2010), 1229-1238, ISSN 8750-7587.

Johnson, J.M. \& Proppe, D.W. (1996). Cardovascular adjustments to heat stress, In. Handbook of Physiology, Section 4: Environmental Physiology, Fregley M.J. \& Blatteis, C.M. (Ed.), 215-243, Oxford University Press, ISBN 0-19-509174-4, New York, NY

Julien, W. E., Martz, F. A., Williams, M., and Garner, G. B. (1974). Feed intake in Hereford calves infused intraperitoneally with toxic fescue extract. Journal of Dairy Science, Vol. 57, (August 1974) 1385-1387, ISSN 1811-9743

Kirch, B.H., Aiken, G.E., \& Spiers, D.E. (2008). Temperature influences on vascular dynamics in cattle measured by Doppler ultrasonography. Journal of Thermal Biology, Vol. 33, (October 2008), 375-379, ISSN 0306-4565

Klotz, J.L., Bush, L.P., Smith, D.L., Shaffer, W.D., Smith, L.L., Vevoda, A.C., Craig, A.M. Arrington, B.C., \& Strickland, J.R. (2006). Assessment of vasoconstrictive potential of D-lysergic acid in an isolated bovine lateral saphenous vein bioassay. Journal of Animal Science, Vol. 84, (September 2006), 3167-3175, ISSN 0021-8812

Klotz, J.L., Bush, L.P., Smith, D.L., Shaffer, W.D., Smith, L.L., Arrington, B.C., \& Strickland, J.R. (2007). Ergovaline-induced vasoconstriction in an isolated bovine lateral 
saphenous vein bioassay. Journal of Animal Science, Vol. 85, (September 2007), 23302336, ISSN 0021-8812

Lee, K., Mincheol, M., Junghee, Y., Juhyun, J. 2004. Spectral waveform analysis of major arteries in conscious dogs by Doppler ultrasonography. Veterinary Radiology and Ultrasonography, Vol. 45, (March 2004), 166-171, ISSN 1058-8083

Lewis, T., \& Gelfand, B. (1935). The manner in which necrosis arises in the fowl's comb under ergot poisoning. Clinical Science., Vol. 2, 43-55, ISSN 0143-5221

Lyons, P.C., Plattner, R.D., Bacon, C.W. (1986). Occurrence of peptide and clavinet ergot alkaloids in tall fescue grass. Science, Vol. 232, (April 1986), 487-489, ISSN 0036-8075

Moneta, G.L., Yeager, R.A., Dalman, R., Antonovic, R., Hall, L.D., \& Porter, J.M. (1992). Duplex ultrasound criteria for diagnosis of splanchnic artery stenosis or occlusion. Journal of Vascular Surgery, Vol. 16, (November 1992), 511-518, ISSN 0741-5214

Müller, M., Hermes, M., Brückmannm, H., \& Schimrigk, K. (1995). Transcranial Doppler ultrasound in the evaluation of collateral blood flow in patients with internal carotid artery occlusion: Correlation with cerebral angiography. American Journal of Neuroradiology, Vol. 16, (January 1995), 195-202, ISSN 0195-6108

Olin, J.W., Piedmonte, M.R., Young, J.R., DeAnna, S., Grubb, M., \& Childs, M.B. (1995). The utility of duplex ultrasound scanning of the renal arteries for diagnosing significant renal artery stenosis. Annals of Internal Medicine, Vol. 122, (June 1995), 833-838, ISSN 0003-4819

Oliver, J.W. (1997). Physiological manifestations of endophyte toxicosis in ruminant and laboratory species. In: Neotyphodium/Grass Interactions, Bacon, C.W., \& Hill, N.E. (Ed.), 311-346, Plenum Press, ISBN 978-0-306-45688-6, New York, NY

Oliver, J.W., Strickland, J.R., Waller, J.C., Fribourg, H.A., Linnabary, R.D., \& Abney, L.K. (1998). Endophytic fungal toxin effect on adrenergic receptors in lateral saphenous veins (cranial branch) of cattle grazing tall fescue. Journal of Animal Science, Vol. 76, 2853-2856, (November 1998), ISSN 0021-8812

Paterson, J., Forcherio, C., Larson, B. Samford, \& Kerley, M. (1995). The effects of fescue toxicosis on beef cattle productivity. Journal of Animal Science, Vol. 73, (March 1992), 889-898, ISSN 0021-8812

Petersen, L.J. Petersen, J.R., Talleruphuus, U., Ladefoged, S.D., Mehlsen, J., \& Jensen, H.E. (1997). The pulsatility index and the resistive index in renal arteries. Associations with long-term progression in chronic renal failure. Nephrology Dialysis Transplantation, Vol. 12 (July 1997), 1376-1380, ISSN 0931-0509

Porter, J.K., \& Thompson, F.N, Jr. (1992). Effects of fescue toxicosis on reproduction in livestock. Journal of Animal Science, Vol. 70, (May 1992), 1594-1603, ISSN 0021-8812

Poulin, M.J., \& Robbins, P.A. (1996). Indexes of flow and cross-sectional area of the middle cerebral artery using doppler ultrasound during hypoxia and hypercapnia in humans. Stroke, Vol. 27, (December 1996), 2244-2250, ISSN 0039-2499

Pozniak, M.A. (2000). Doppler ultrasound of the liver. In: Clinical Doppler Ultrasound, Allan, P.L. (Ed.), 141-184, Churchill Livingstone, ISBN 84-8174-566-9, London, UK

Raisis, A.L., Young, L.E., Meire, H.B., Taylor, P.M., Walsh, K., \& Lekeux P. (2000). Variability of Doppler ultrasound measurements of hindlimb blood flow in conscious horses. Equine Veterinary Journal, Vol. 32 (March 2000), 125-132, ISSN 2042-3306

Rhodes, M.T., Paterson, J.A., Kerley, M.S., Garner, H.E., \& Laughlin, M.H. (1991). Reduced blood flow to peripheral and core body tissues in sheep and cattle induced by 
endophyte-infected tall fescue. Journal of Animal Science, Vol. 69, (May 1991) 20332043, ISSN 0021-8812

Rottinghaus, G.E., Garner, G.B., Cornell, C.N., \& Ellis J.L. (1991). HPLC method for quantitating ergovaline in endophyte-infected tall fescue: Seasonal variation of ergovaline levels in stems with leaf sheaths, leaf blades, and seed heads. Journal of Agricultural Food and Chemistry, Vol. 39, (January 1991), 112-115, ISSN 0021-8561

Schmidt, W.A., Kraft, H.E., Vorpahl, K., Völker, L., \& Gromnica-Ihle, J. (1997). Color duplex ultrasonography in the diagnosis of temporal arteritis. The New England Journal of Medicine, Vol. 337 (November 1997), 1336-1340, ISSN 0028-4793

Schoning, C., Flieger, M., \& Pertz, H. H. (2001). Complex interaction of ergovaline with 5HT2A, 5-HT1B/1D, and alpha 1 receptors in isolated arteries of rat and guinea pig. Journal of Animal Science, Vol. 79, (August 2001) 2202-2209, ISSN 0021-8812

Shappell, N. W. (2003). Ergovaline toxicity on CACO-2 cells as assessed by MTT, alamarblue and DNA assays. In Vitro Cellular Developmental Biology Animal, Vol. 39, (July 2003) 329-335, ISSN0143-5221

Siegel, M.R., Latch, G.C.M., \& Johnson, M.C. (1985). Acremonium fungal endophytes of tall fescue and perennial ryegrass: Significance and control. Plant Disease, Vol. 69, (February 1985), 179-183, ISSN 0191-2917

Sites, B.D., Brull, R., Chan, V.W.S. Spence, B.C., Gallagher, J., Beach, M.L., Sites, V.R., \& Hartman, G.S. (2007). Artifacts and pitfalls errors associated with ultrasoundguided regional anesthesia. Part I: Understanding the basic principles of ultrasound physics and machine operations. Regional Anesthesia and Pain Medicine, Vol. 32, (September 2007), 419-433, ISSN 1098-7339

Someda, H., Moriyasu, F., Masazumi, F, Hamata, N., Nabeshima,M., Nishikawa, K., Okuma, M., Tanaka, K., \& Ozawa, K. (1995). Vascular complications in living related liver transplantation detected with intraoperative and postoperative Doppler US. Journal of Hepatology, Vol. 22, (June 1995), ISSN 0168-8278

Strickland, J. R., Aiken, G. E., \& Klotz, J. L. (2009a). Ergot alkaloid-induced blood vessel dysfunction contributes to fescue toxicosis. In: Forage and Grazinglands. Date of access: 8/2/2011. Retrieved from:

http://www.plantmanagementnetwork.org/sub/fg/review/2009/ergot/

Strickland, J. R., Aiken, G. E., Spiers, D.E., Fletcher, L. R., \& Oliver, J. W. (2009b). Physiological Basiss of Fescue Toxicosis. In: Tall Fescue for the Twenty-First Century. Fribourg, H.A., Hannaway, D.B., \& West, C.P. (Eds.) 203-227, ASA, CSSA, SSSA. ISBN 978-0-89118-172-9, Madison, WI

Strickland, J. R., Bailey, E. M., Abney, L. K., \& Oliver, J. W. (1996). Assessment of the mitogenic potential of the alkaloids produced by endophyte Acremonium coenophialum-infected tall fescue (Festuca arundinacea) on bovine vascular smooth muscle in vitro. Journal of Animal Science, Vol. 74 (July 1996) 1664-1671, ISSN 00218812

Strickland, J.R., Looper, M.L., Matthews, J.C., Rosenkrans, C.F., Jr. Flythe, M.D., \& Brown, K.R. (2011). St. Anthony's Fire in livestock: Causes, mechanisms, and potential solutions. Journal of Animal Science, Vol. 89, (May 2011), 1603-1626, ISSN 0021-8812

Walls, J. R., \& Jacobson, D. R. (1970). Skin temperature and blood flow in the tail of dairy heifers administered extracts of toxic tall fescue. Journal of Animal Science, Vol. 30, (March 1970), 420-423, ISSN 0021-8812 
Wemdelhag, I, Gustavsson, T.,Suurküla, Berglund, G., \& Wikstrand, J. (1991). Ultrasound measurement of wall thickness in the carotid artery: Fundamental principles and description of a computerized analyzing system. Clinical Physiology, Vol. 11, (November 1991), 566-577, ISSN 1475-0961

Whelan, J.F., \& Barry, M.H. (1992). Color flow doppler ultrasonography with peripheral arteriography for the investigation of peripheral vascular disease. Journal of Clinical Ultrasound, Vol. 20, (July 1992), 369-374, ISSN 0091-2751

Williams, M., Shaffer, S. R., Garner, G. B., Yates, S. G., Tookey, H. L., Kintller, L. D., Nelson, S. L., \& McGinity, J. T. (1975). Induction of fescue foot syndrome in cattle by fractionated extracts of toxic fescue hay. American Journal of Veterinary Research, Vol. 36, (September 1975) 1353-1357, ISSN 0002-9645

Zagzebski, J.A. (2000). Physics and instrumentation in Doppler and B-mode ultrasonography, In: Introduction to Vascular Ultrasonography, Zwiebel, W.J. (Ed.), 17-43, W.B. Saunders Co., ISBN 0-7216-6949-2, Philadelphia, PA

Zanzalari, K.P., Heitmann, R.N., McLaren, J.B., Fribourg, H.A. (1989). Effects of endophyteinfected fescue seed and cimetidine on respiration rates, rectal temperatures and hepactic mixed function oxidase activity as measured by hepatic antipyrine metabolism in sheep. Journal of Animal Science, Vol. 67, (December 1989), 3370-3378, ISSN 0021-8812 


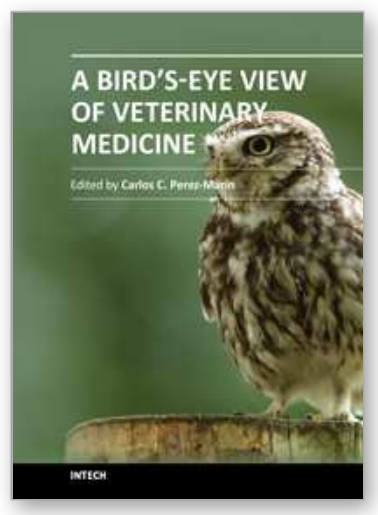

\author{
A Bird's-Eye View of Veterinary Medicine \\ Edited by Dr. Carlos C. Perez-Marin
}

ISBN 978-953-51-0031-7

Hard cover, 626 pages

Publisher InTech

Published online 22, February, 2012

Published in print edition February, 2012

Veterinary medicine is advancing at a very rapid pace, particularly given the breadth of the discipline. This book examines new developments covering a wide range of issues from health and welfare in livestock, pets, and wild animals to public health supervision and biomedical research. As well as containing reviews offering fresh insight into specific issues, this book includes a selection of scientific articles which help to chart the advance of this science. The book is divided into several sections. The opening chapters cover the veterinary profession and veterinary science in general, while later chapters look at specific aspects of applied veterinary medicine in pets and in livestock. Finally, research papers are grouped by specialisms with a view to exploring progress in areas such as organ transplantation, therapeutic use of natural substances, and the use of new diagnostic techniques for disease control. This book was produced during World Veterinary Year 2011, which marked the 250th anniversary of the veterinary profession. It provides a fittingly concise and enjoyable overview of the whole science of veterinary medicine.

\title{
How to reference
}

In order to correctly reference this scholarly work, feel free to copy and paste the following:

G.E. Aiken and J.R. Strickland (2012). Doppler Ultrasonography for Evaluating Vascular Responses to Ergopeptine Alkaloids in Livestock, A Bird's-Eye View of Veterinary Medicine, Dr. Carlos C. Perez-Marin (Ed.), ISBN: 978-953-51-0031-7, InTech, Available from: http://www.intechopen.com/books/a-bird-s-eye-view-ofveterinary-medicine/doppler-ultrasonography-for-evaluating-vascular-responses-to-ergopeptine-alkaloids-inlivestock

\section{INTECH}

open science | open minds

\section{InTech Europe}

University Campus STeP Ri

Slavka Krautzeka 83/A

51000 Rijeka, Croatia

Phone: +385 (51) 770447

Fax: +385 (51) 686166

www.intechopen.com

\section{InTech China}

Unit 405, Office Block, Hotel Equatorial Shanghai

No.65, Yan An Road (West), Shanghai, 200040, China 中国上海市延安西路65号上海国际贵都大饭店办公楼 405 单元

Phone: +86-21-62489820

Fax: $+86-21-62489821$ 
(C) 2012 The Author(s). Licensee IntechOpen. This is an open access article distributed under the terms of the Creative Commons Attribution 3.0 License, which permits unrestricted use, distribution, and reproduction in any medium, provided the original work is properly cited. 